\title{
PEMAHAMAN PENGUSAHA DALAM PENERAPAN CSR OLEH PT. INDOCEMENT TUNGGAL PRAKASA, TBK. DI CITEUREUP BOGOR
}

\author{
Feliza Zubair \\ Program Studi Hubungan Masyarakat, Fakultas Ilmu Komunikasi, Universitas Padjadjaran
}

\begin{abstract}
ABSTRAK
CSR adalah tanggung jawab sosial perusahaan dimana melalui kegiatan ini, perusahaan berusaha membina interaksi dengan lingkungan untuk menciptakan saling pengertian dan saling memiliki. Salah satunya PT. Indocement Tunggal Prakasa, Tbk. Penelitian ini bertujuan untuk mengetahui latarbelakang PT. Indocement Tunggal Prakasa, Tbk. melakukan pendekatan etis melalui reklamasi budidaya tanaman jarak (Energy Crops) pada lahan bekas galian tambang, mengetahui pemaknaan pengusaha terhadap penerapan CSR oleh PT. Indocement Tunggal Prakasa, Tbk di Citeureup Bogor. Pendekatan penelitian yang digunakan adalah kualitatif, dengan paradigma konstruktivisme, dan jenis studi adalah Studi Kasus. Subjek Penelitian adalah pimpinan departmen CSR dan PT. Indocement Tunggal Prakasa, Tbk. di Palimanan Cirebon dan di Citeureup Bogor yang dipilih secara purposive. Pengumpulan data diperoleh melalui wawancara mendalam, observasi langsung, serta analisis dokumen. Program-program yang dilaksanakan dalam upaya pengembangan Energi Crops adalah melakukan revitalisasi dan reklamasi pada lahan marginal dan lahan bekas penambangan dengan tanaman Jarak Pagar, Kemiri Sunan, Nyamplung, King Grass, Sorgum, yang dapat diolah menjadi biofluel dan berbagai tanaman "keras" seperti pohon Jati, pohon Jinjing yang dapat mengembalikan hara tanah (menyuburkan). Upaya lain adalah melakukan berbagai inovasi agar dapat memaksimalkan penggunaan energi alternatif terutama sebagai pengganti batubara. Biofluel yang ramah lingkungan akan dapat mengurangi berbagai dampak buruk akibat operasional perusahaan pertambangan seperti berkurangnya polusi, emisi dan dampak lainya. Dengan program ini diharapakan masyarakat dapat teredukasi utntuk ikut memelihara lingkungan berkelanjutan.
\end{abstract}

Kata-kata Kunci: Tanggung jawab sosial perusahaan, tanaman energi, public relations, masyarakat

\section{THE MANAGEMENT COMPREHENTION IN APPLICATION OF CSR PT. INDOCEMENT TUNGGAL PRAKASA, TBK. IN CITEUREUP BOGOR}

\begin{abstract}
CSR is a corporate social responsibility which through these activities, the company attempted to build interaction with the environment to create mutual understanding and belonging. One of them is PT. Indocement Tunggal Prakarsa Tbk. This study aims to determine the background PT. Indocement Tunggal Prakasa Tbk ethical approach cultivation through reclamation distance (Energy Crops) on land mines dug, knowing the meaning of employers towards the implementation of CSR by PT. Indocement Tunggal Prakasa Tbk in Citeureup Bogor know the meaning employers towards the implementation of CSR in Coventry Bogor. The research applies qualitative research approach, utilizing paradigm of constructivism, and the type of study are Case Study. The research subject is the CSR department of PT. Indocement Tunggal Prakasa Tbk. in Citeureup Bogor. Subjects are purposively selected. The collection of data obtained through in-depth interviews, direct observation, and document analysis. The programs are implemented in the development of the Energy Crops is to revitalize and on marginal land and reclamation of mined land with Jatropha Parar, Pecan Sunan, Nyamplung, King Grass, Sorghum, which can be processed into a variety of plants biofluel and "hard" like a tree teak, trees Gear can restore soil nutrients (fertilize). Another effort is to perform a variety of innovations in order to maximize the use of alternative energy, especially as a replacement for environmentally friendly batubara.Biofluel will be able to mitigate some of the harmful effects of mining operations such as reduced pollution, emisis and other impacts. With this program DAPT educated people expected to participate utntuk maintaining a sustainable environment .
\end{abstract}

Keywords: Corporate social responsibility, energy crops, public relations, society

Korespondensi: Dr. Feliza Zubair, M.Si. Program Studi Hubungan Masyarakat, Fakultas Ilmu Komunikasi Universitas Padjadjaran, Jl. Raya Bandung-Sumedang Km.21. Email: felizaherison@yahoo.co.id 


\section{PENDAHULUAN}

\section{CSR (corporate social responsibility)} adalah tanggung jawab sosial perusahaan dimana melalui kegiatan ini banyak perusahaan berusaha membina interaksi dengan lingkungan untuk menciptakan saling pengertian dan saling memiliki. Begitu pula dengan perusahaan pertambangan yang tidak dapat terlepas dari tanggung jawab tersebut. Berbagai kasus pelanggaran yang merugikan komunitas kerap terjadi di berbagai area pertambangan di tanah air, misalnya pembuangan air limbah penambangan batu bara di lahan warga sementara air limbah tersebut memiliki tingkat keasaman yang tinggi dan dapat mengakibatkan kulit melepuh, organ-organ tubuh rusak serta kematian bagi yang menggunakannya. Ini adalah fakta yang menggambarkan betapa besar resiko yang harus ditanggung oleh masyarakat sekitar lahan pertambangan akibat kecerobohan perusahaan. Adapula warga sekitar pertambangan yang menderita sesak napas bahkan penyakit paruparu, akibat polusi udara akibat industri pengolahan tambang kapur dan lainnya.

Untuk itu perusahaan perlu menerapkan etika bisnis yang etis dalam kegiatan CSR sebagai bentuk tanggung jawab terhadap komunitas yang sudah dirugikan oleh keberadaannya. Berbagai upaya perusahaan selama ini seperti memberikan kesempatan kerja, memenuhi kebutuhan masyarakat, memberikan sumbangan, memperbaiki sarana dan prasarana umum dan sebagainya ditujukan untuk mendapat dukungan dari masyarakat. Namun secara bisnis etis perusahaan harus berupaya untuk memperkecil dampak buruk akibat operasional perusahaannya kendati biayanya tidak sedikit.

Di Indonesia CSR masih merupakan etika bisnis yang tidak tertulis sebelum diundangkannya Undang-undang No.40 Tahun 2007 tentang Perseroan Terbatas dan Undangundang No. 25 Tahun 2007 tentang Penanaman Modal tercantum Pasal 15. Undang-undang penanaman modal tersebut berisi antara lain bahwa kewajiban setiap penanam modal untuk menerapkan pengelolaan yang baik dalam perusahaannya, antara lain melaksanakan tanggung jawab sosial perusahaan, membuat laporan kegiatan penanaman modal juga mematuhi peraturan/ undang-undang yang berlaku. Yang dimaksud tanggung jawab sosial adalah suatu usaha dari penanam modal untuk menciptakan hubungan yang baik dengan lingkungan. Sedangkan pada Pasal 74 UndangUndang Perseroan Terbatas berisi antara lain bahawa Perseroan yang menjalankan kegiatan usahanya di bidang sumber daya alam wajib melaksanakan Tanggung Jawab Sosialnya, dan bila Perseroan tidak melaksanakan kewajiban Tanggung Jawab Sosial dan Lingkungan akan dikenai sanksi, yaitu segala bentuk sanksi yang diatur dalam peraturan perundang-undangan. Tanggung jawab ini juga berkaitan dengan tanggung jawab kepada konsumen, pemegang saham serta karyawan perusahaan.

Kehadiran undang-undang di atas merupakan sikap ikut campur pemerintah terhadap kewajiban moral perusahaan. Hal ini menimbulkan kesan adanya penyerahan sebagian beban pemerintah kepada perusahaan. Kenyataan in menimbukan beragam tanggapan perusahaan terhadap kewajiban CSR. Setiap perusahaan memiliki persentase tersendiri untuk kegiatan CSR yang dilakukannya. Namun yang terpenting adalah dengan melakukan CSR setidaknya perusahaan telah melakukan investasi jangka panjang yakni bagi keberlanjutan perusahaan tersebut.

Berbagai alasan disampaikan namun yang jelas setiap perusahaan mempunyai kepentingan serta pemaknaan yang berbedabeda terhadap kegiatan CSR yang dilakukan. Demikian juga dengan PT. Indocement Tunggal Prakasa, Tbk yang berlokasi di Citeureup Bogor. Menurut General Affair Departemen CSR nya, Bapak Aditiya untuk PT. Indocement sendiri CSR itu bukan kewajiban perusahaan terhadap lingkungan, melainkan kebutuhan yaitu sejauh mana perusahaan dapat membantu komunitas untuk memenuhi kebutuhannya. Salah satu program yang diunggulkan adalah program Budidaya Tanaman Jarak dan Energy Crops menduduki tempat yang istimewa dan membawa perusahaan pada peringkat Green dan Gold Proper dari Kementerian Lingkungan Hidup, suatu penghargaan bagi perusahaan industri yang peduli pada lingkungan hidup. Artikel ini memaparkan hasil penelitian tentang pemaknaan pengusaha terhadap penerapan CSR oleh PT. Indocement Tunggal Prakasa, Tbk di Citeureup Bogor. 


\section{METODE PENELITIAN}

Metode yang digunakan dalam penelitian ini adalah metode kualitatif dengan pendekatan studi kasus, karena objek penelitian yang dikaji merupakan sistem yang unik, spesifik dan khusus, yaitu perusahaan pertambangan yang melakukan kegiatan $C S R$ sebagai bentuk tanggung jawab perusahaan terhadap lingkungan namun didasari oleh kesadaran perusahaan dan kepatuhan perusahaan terhadap etika bisnis. Peneliti mencoba mengungkapkan fakta-fakta baru dalam program CSR PT. Indocement Tunggal Prakasa, Tbk. yang kemudian dapat diadaptasi serta digeneralisasikan pada perusahaan-perusahaan tambang lainnya yang memiliki situasi dan kondisi yang sama dengan PT. Indocement. Tehnik pengumpulan data dalam penelitian ini adalah wawancara mendalam, observasi dan studi kepustakaan.

Teori yang digunakan adalah teori Interaksionisme Simbolik dari Herbert Blumer dan George Herbert Mead, teori Konstruksi Sosial Atas Realitas dari Berger dan Luckman, juga beberapa konsep CSR dan etika bisnis dari pendekatan Public Relations.

Penelitian ini menggunakan model pengambilan sampel purposive yaitu: penarikan sampel yang ditentukan selaras dengan tujuan studi (Agus Salim,2006: 12), maka dalam penelitian ini sampel yaitu narasumber pada Departemen CSR PT. Indocement Tunggal Prakasa, Tbk. di Citeureup-Bogor, yang memenuhi ketetapan sebagai berikut: (1) Subjek Penelitian bersedia menerima kehadiran peneliti, dan (2) Subjek penelitian mampu dan mau mengutarakan pengalaman-pengalaman yang relevan dengan penelitian.

Untuk narasumber ditetapkan Bapak R.Aditya Purnama, selaku CSR Departement Head PT. Indocement Tunggal Prakasa, Tbk. dan Bapak Fajar Fathoni selaku CSR Officer PT. Indocement Tunggal Prakasa Tbk.

\section{HASIL DAN PEMBAHASAN}

Sebagai perusahaan Semen terkemuka di Indonesia PT. Indocement Tunggal Prakasa, Tbk. lokasi Citeureup mendapat banyak sorotan terutama berkaitan dengan kondisi 9 pabrik yang berada di satu lokasi. Hal ini sudah tentu menimbulkan berbagai dampak buruk kepada lingkungan sekitarnya, baik dampak akibat penambangan maupun dampak operational pabrik seperti polusi dan pemanasan global. Namun dilandasi tanggung jawab serta kepedulian terhadap lingkungan, maka perusahaan melakukan program bina lingkungan yang kemudian berubah menjadi program CSR . PT. Indocement Tunggal Prakasa, Tbk. lokasi Citeureup secara keseluruhan memiliki 12 desa binaan, antara lain Desa Bantar Jati dengan penduduk yang cukup padat yang memiliki beragam profesi, ada pula Desa Hambalang, Desa Klapanunggal dan Desa Citeureup. Perusahaan memahami CSR sebagai alat atau media adaptasi perusahaan dengan komunitas, antara lain konsep program 5 Pilar yang fokus pada penanggulangan kemiskinan, pendidikan dan lingkungan. Program 5 pilar ini meliputi bidang: Pendidikan, kesehatan, ekonomi, sosial dan budaya serta olah raga (sosbudgar) serta keamanan, dirancang untuk memenuhi kebutuhan strata sosial berbeda di masyarakat (komunitas). Dalam pelaksanaannya, PT. Indocement Citeureup melibatkan masyarakat guna memperluas manfaat pemberdayaan.

Adapun program-program yang berkaitan langsung dengan tanggung jawab terhadap berbagai dampak yang diakibatkan operasional perusahaan, maka dilaksanakan berbagai program guna meminimalisir dampak negatif tersebut, antara lain misi clean industry dengan memasang alat penangkap debu di setiap pabrik berupa electrostatic precipitator dan bag filter, juga penerapan $3 \mathrm{R}$ yaitu: reduce, reuseu, recycle antara lain dalam pemanfaatan bahan bakar dan bahan baku alternatif pada proses produksi, penghematan energi di segala bidang, seperti listrik, dan bahan bakar serta menerapkan proyek mekanisme pembangunan bersih. Mekanisme pembangunan bersih merupakan bentuk dukungan perusahaan dalam menghadapi pemanasan global, terdiri dari proyek blended cement dan proyek bahan bakar alternatif.

Untuk kedua proyek tersebut PT. Indocement Tunggal Prakasa, Tbk mendapat certification of emission reduction (CER) dari United Nations Framework Convention on Climate Change (UNFCCC). Ini merupakan hasil usaha kesungguhan perusahaan dalam penerapan clean development mecanism (CDM). Disamping itu perusahaan sangat fokus terhadap budidaya tanaman alternatif atau energy corps. 
Di lahan-lahan marjinal bekas tambang, apa yang dilakukan oleh perusahaan tampaknya bukan sekedar tanggung jawab atau realisasi dari etika bisnis semata, melainkan berangkat dari kesadaran akan pentingnya nilai kebersamaan. Salah satu tujuan utama dalam berbagi nilai kebersamaan ini adalah menanamkan kesadaran akan menjaga lingkungan berkelanjutan melalui revitalisasi lahan dan reklamasi. PT. Indocement menegaskan bahwa ini bukan sekedar tanggung jawab perusahaan terhadap lingkungan maupun komunitas, melainkan menjadi kebutuhan bersama untuk memiliki lingkungan sehat. Untuk itu dalam setiap program perusahaan selalu melibatkan komunitas.

Menurut Cresswell, (2011: 4) dalam penelitian kualitatif tidak ada kebenaran yang mutlak melainkan mengeksplorasi dan memahami makna yang oleh sejumlah individu atau sekelompok orang dianggap berasal dari masalah sosial atau kemanusiaan. Program pengembangan energi alternatif atau Energy Crops dalam penelitian ini diperoleh dari hasil pertukaran simbol yaitu simbol yang signifikan dalam salah satu unit atau dengan kata lain merupakan hasil kesepakatan bersama para pengelola $C S R$ di PT. Indocement Citeureup.

Untuk menjelaskan lebih jauh tentang konstruksi makna ini maka peneliti lebih dulu mengungkapkan simbol-simbol yang disepakati bersama oleh pihak perusahaan dengan menggunakan teori Interaksionisme Simbolik dari George Herbert Mead. Setelah itu peneliti akan melakukan pembahasan mengenai maknamakna yang dikonstruksi dengan menggunakan teori konstruksi sosial atas realitas dari Berger dan Luckmann. Teori Interaksionisme Simbolik diawali oleh Herbert Blumer yang menyampaikan tentang tiga prinsip utama yaitu pemaknaan (meaning), bahasa (language) dan pikiran (thought).

Premis pertama dari Blumer yaitu Human act toward people or things on the basis of the meanings they assign to those people or things. Tindakan seseorang terhadap orang lainnya pada dasarnya dilandasi oleh pemaknaannya (persepsinya) tentang orang lain tersebut.

Maka dalam penelitian ini PT. Indocement operasional Citeurup Bogor melaksanakan CSRnya berdasarkan kepada pemaknaan manajemen tentang situasi, kondisi, budaya dan sikap hidup masyarakat sekitar perusahaan (komunitas). Untuk keberhasilan program lebih dahulu dilakukan survei yang kemudian sampai pada pemahaman akan kebutuhan komunitas. Pihak perusahaan paham akan karakteristik budaya komunitas Citeureup yang unik, mata pencaharian penduduk yang beragam (Petani,pedagang,perbengkelan dan sebagainya). Program pengembangan energi alternatif berangkat dari pengetahuan menejemen tentang besarnya dampak buruk yang diakibatkan oleh operasional produksi semen dengan menggunakan bahan bakar batu bara, tingkat polusi yang tinggi, emisi akibat panas yang tinggi dalam pengolahan semen,disamping lahan-lahan marginal akibat penambangan yang perlu direvitalisasi dan dilakukan reklamasi.

Penduduk Citeureup memiliki mata pencaharian yang beragam seperti bertani, industri, pedagang dan bengkel. Adapun tanaman jarak pagar awalnya merupakan tanaman yang tumbuh liar di lahan mereka. Pohon jarak pagar memiliki sejarah panjang, digunakan oleh bangsa Indonesia sejak dulu baik sebagai obat, maupun sebagai bahan bakar pengganti minyak tanah. Salah satu sejarah mengatakan Jarak Pagar ini dibawa oleh pasukan Jepang ke Indonesia dan dibudidayakan di Indonesia untuk energi alternatif pesawat Jepang. Dan oleh bangsa kita minyak dari buah Jarak Pagar digunakan sebagai pelumas senjata para prajurit kita untuk melawan penjajah (Jepang). Berbekal latar belakang budaya tersebut, juga didasari ketentuan dari pemerintah yang menganjurkan budidaya tanaman jarak pada lahan marginal, maka dilakukan program budidaya tanaman jarak sebagai energi alternatif pengganti energi fosil yang makin berkurang jumlahnya.

Kembali pada premis Blumer maka pemaknaan pengusaha tentang kenyataan komunitas pada hakekatnya berasal dari apa yang diyakini pengusaha sebagai kenyataan itu sendiri (once people define a situation is real, its very real in its concequences). Menurut Bapak Aditya $C S R$ bagi mereka bukan tanggung jawab terhadap lingkungan, melainkan suatu upaya untuk memenuhi kebutuhan komunitas (nilai kebaikan).

Premis Blumer yang kedua adalah: meaning arises out of the social interaction that people have with each other. Pemaknaan muncul dari interaksi sosial yang terjadi diantara mereka. Pertukaran informasi yang terjadi antara pihak perusahaan dengan komunitas merupakan 
proses pertukaran simbol (bahasa) yang akan memunculkan pemaknaan perusahaan terhadap komunitas.

Pemaknaan inilah yang menjadi dasar dari dibuatnya program-program CSR PT. Indocement Tunggal Prakasa, Tbk.. Salah satu media komunikasi yang paling efektif dalam interaksi ini adalah Bina Lingkungan Komunikasi atau BILIKOM, yang dibentuk oleh perusahaan sebagai wadah sebagai media komunikasi perusahaan dengan komunitas. Anggota yang bergabung dari pihak eksternal antara lain Kepala Desa, Karang Taruna, serta opinion leader dari tiap desa dan dari pihak perusahaan adalah wakil-wakil bidang terkait seperti keamanan, operasional pabrik dan lain-lain sesuai kepentingannya. BILIKOM di Citeureup Bogor hanya melakukan dua atau tiga kali pertemuan dalam satu tahun, Dalam pertemuan dibahas berbagai program yang akan dilaksanakan, bagaimana pelaksanaannya, bagaimana evaluasi kegiatan yang sedang atau sudah berjalan, dari hasil sharing ini kemudian muncul pemaknaan itu.

Premis ketiga Blumer adalah an individual's interpretation of symbols is modified by his or her own thought process. Interaksionisme simbolik menggambarkan proses berpikir sebagai perbincangan dengan diri sendiri. Proses berpikir ini sendiri bersifat reflektif. Menurut Mead sebelum manusia berpikir, kita butuh bahasa untuk dapat berkomunikasi secara simbolik. Cara bagaimana manusia berpikir banyak ditentukan oleh praktek bahasa, interaksionisme simbolik melihat posisi bahasa lebih sebagai seperangkat ide yang dipertukarkan kepada pihak lain secara simbolik. Menurut Immanuel Kant dalam Rahmat (2008: 26), manusialah yang menciptakan simbol-simbol itu, karena pada dasarnya manusia adalah mahluk yang aktif. Jiwa menafsirkan pengalamamn indrawi secara aktif, seperti mencipta, mengorganisasikan, menafsirkan bahkan mendistorsi realitas. PT. Indocement bersama komunitas menciptakan simbol-simbol yang kemudian mereka sepakati bersama dalam bentuk-bentuk program yang menciptakan lingkungan berkelanjutan. (Lihat gambar 1).

Perbedaan penggunaan bahasa pada akhirnya juga menentukan perbedaan cara berpikir manusia tersebut, akan tetapi walaupun pemaknaan suatu bahasa banyak ditentukan oleh konteks atau kontruksi sosial, sering kali interpretasi individu sangat berperan di dalam modifikasi simbol yang kita tangkap dalam proses berpikir, kita mencernanya kembali dalam proses berpikir sesuai dengan persepsi diri kita masing-masing. Dalam penelitian ini budaya perusahaan sangat menentukan cara berpikir perusahaan, seperti etika yang dianut perusahaan direalisaikan dalam bentuk simbolsimbol tanggung jawab moral perusahaan terhadap komunitas. Dari hasil penelitian diperoleh beberapa simbol yang dipersepsi perusahaan sebagai hasil interaksinya dengan komunitas melalui BILIKOM yaitu: tanggung jawab ekonomi, tanggung jawab legal, tanggung jawab lingkungan serta tanggung jawab sosial.

Pemaknaan dan proses berpikir merujuk kepada bahasa. Bahasa menentukan bagaimana proses pemaknaan dan proses berpikir. Interkasi ketiganya adalah yang menjadi kajian utama dalam perspektif interaksionisme simbolik, dimana pada hakekatnya komunikasi adalah suatu proses interaksi simbolik antara pelaku komunikasi. Dalam hal ini perusahaan mengembangkan simbol tanggung jawab ke dalam program Energy Crops, yaitu bentuk pendekatan etis perusahaan melalui pengembangan energi alternatif serta tindakan mengurangi emisi dan polusi. Simbol-simbol di interpretasikan dalam budidaya Tanaman Jarak Pagar, Nyamplung, Kemiri Sunan, dan beberapa tanaman lain seperti Pohon Jati.

Konsep Blumer dikembangkan oleh Mead (George Herbert Mead) menjadi tiga konsep yang mendasar yaitu Mind, Self dan Society. Mind adalah bagian yang ada dalam diri (intra persona) yang menafsirkan lingkungan serta kemudia melakukan respon pada stimuli yang menghampirinya. Self adalah Bagian diri yang berinteraksi dengan lingkungan, dimana self memiliki konsep diri dan seperangkat pengalaman yang menyertai interaksinya. Society adalah masyarakat yang melakukan interaksi (bertukar simbol) dengan self.

Konsep Mead tentang 'diri' (self). Konsep diri menurut Mead sebenarnya kita melihat diri kita lebih kepada bagaimana orang lain melihat diri kita (imagining how we look to another person). Interaksionisme simbolik melihat gambaran mental ini sebagai the looking glass self dan bahwa hal tersebut dikonstruksikan secara sosial. Dalam konsepsi interaksionisme simbolik dikatakan bahwa kita cenderung menafsirkan diri kita seperti bagaimana orang- 
orang melihat atau menafsirkan diri kita. Seringkali konsep diri kita bentuk sebagai upaya untuk memenuhi harapan atau tafsiran orang lain tersebut kepada diri kita.

Dalam penelitian ini PT. Indocement Tunggal Prakasa, Tbk. mengkonsepkan perusahaannya sebagai perusahaan yang peduli pada lingkungan serta keberlanjutan lingkungan, yaitu "Green Company". Konsep diri ini terbentuk tidak saja untuk memenuhi harapan komunitas dan stakeholder lainnya dimana sebagai perusahaan pertambangan dan industri semen sangat indentik dengan pengerusakan alam. Konsep diri ini juga merupakan hasil "bercermin" perusahaan yang memiliki etika bisnis sehingga merancang setiap tindakannya tidak terlepas dari gambaran dirinya ini. (lihat gambar 2).

Dari hasil penelitian yang berupa wawancara dengan Bapak Aditya selaku CSR Head Departemen dengan Bapak Fajar selaku CSR Officer, tampak setiap program yang dilakukan perusahaan tidak lepas dari konsep dirinya sebagai "Green Company".

Pada saat Self melakukan interaksi simboliknya dengan komunitas (bilikom), maka terjadi proses pertukaran simbol yang signifikan dan disepakati diantara mereka dalam program CSR. Makna atas simbol yang mereka pahami ini akan semakin sempurna dengan adanya interaksi diantara perusahaan dengan BILIKOM maupun perusahaan dengan stakeholde lainnya, juga BILIKOM dengan komunitas yang diwakilinya. Simbol-simbol yang dipahami bersama diantara perusahaan dengan komunitas (Bilikom) inilah yang menurut Blumer merupakan bahasa yang mengikat aktifitas diantara mereka serta stakeholder perusahaan, juga interaksi dengan masyarakat luas (society).

Teori interaksi Simbolik membantu menjelaskan bagaimana perusahaan memandang "dirinya" sebagai "Green Company" yang , bagaimana perusahaan melakukan CSRnya berlandaskan etika (bisnis) yang dianut oleh perusahaan itu, yang kemudian diwujudkan dalam program pengembangan energi alternatif (Energy Crops), untuk selanjutnya diwujudkan dalam simbol-simbol tanggungjawab perusahaan (ekonomi, legal, lingkungan dan sosial). Apa yang dilakukan ini merupakan tindakan perusahaan berdasarkan pandangan atas "dirinya", baik pandangan diri sendiri maupun pandangan komunitas, stakeholder dan pihak lain kepada perusahaan.

Pertukaran simbol yang terjadi antara perusahaan dengan komunitas yang berdasar pada konsep diri perusahaan (Green Company) telah mengembangkan program energi alternatif ke dalam berbagai program CSR yang merupakan realisasi tanggung jawab moral perusahaan terhadap komunitas maupun stakeholder. PT. Indocement memaknai tanggung jawab ini sebagai aktifitas yang harus dilakukan dengan sungguh-sungguh dan sepenuh hati. Mengenai hal ini peneliti mendengar langsung baik dari bapak Adhitya maupun Bapak Fajar, juga menyaksikan langsung dari observasi dilapangan tentang berbagai upaya yang telah dilakukan untuk keberhasilan program pengembangan energi alternatif ini. Seperti betapa pun besarnya kesulitan yang dialami dalam program budidaya tanaman jarak pagar tetapi perusahaan terus menerus melakukan berbagai percobaan untuk dapat menemukan metode penanaman yang tepat dengan hasil yang maksimal. Keberhasilan ini akan berpengaruh pada serangkaian siklus panjang yang dapat memberikan banyak kebaikan baik bagi perusahaan maupun komunitas. Tanaman yang berhasil tumbuh dengan baik akan menyerap karbon dioksida, mengurangi polusi, mengurang emisi, buahnya diolah menjadi energi pengganti yang lebih ramah lingkungan; dan bagi komunitas akan mendapat penghasilan (meningkat secara ekonomi) dari produksi buah Jarak Pagar (ditanam sendiri) dan pengelolaan tanaman Jarak Pagar (di lahan PT. Indocement).

Serangkaian keuntungan lain adalah dalam upaya revitasisasi lahan-lahan marginal yang sulit digarap untuk tumbuhan konsumtif, dengan membudi dayakan tanaman energi alternatif, maka lahan-lahan bekas galian tambang maupun disekitar tambang dapat bermanfaat kembali bagi kehidupan. Selain tanaman Jarak Pagar dikembangkan pula budidaya tanaman energi alternatif lain seperti King Grass yang rumputnya berguna untuk makanan ternak, sebagai penghijauan juga, dan umbinya untuk energi alternatif. Menurut pengelola P3M PT. Indocement, King Grass memiliki akar serabut sehingga tidak merusak struktur tanah, membudidayakannya lebih mudah dari Jarak Pagar dan kandungan energinya lebih besar dari tanaman Jarak pagar.

Metode dalam penelitian ini adalah kualitatif dengan pendekatan studi kasus tunggal 
dengan multi level analysis. Menurut Mooney dalam Agus Salim (2006) bahwa studi kasus tunggal dengan multi level analisis dimaksud untuk menyoroti perilaku individu atau kelompok individu dengan berbagai tingkatan masalah penting. Dalam penelitian ini peneliti membahas mengenai pemaknaan tanggung jawab moral perusahaan yang diaplikasikan dalam kegiatan CSR PT. Indocement melalui program pengembangan energi alternatif (enegy crops). Sebagai bisnis etis program-program itu berjalan berkesinabungan, saling pengaruh dan mempengaruhi, dari penggunaan energi alternatif yang lebih ramah lingkungan, emisi berkurang, polusi berkurang,

P3M PT. Indocement operational Citeureup merupakan bukti reklamasi dan revitalisasi lahan pasca tambang. Bangunan serta berbagai fasilitas termasuk kebun dan peternakan dibangun di atas lahan bekas penambangan tanah liat di Desa Hambalang. Bukan hal yang mudah mewujudkan perkebunan di lokasi marjinal seperti ini, jangankan untuk bertanam, membuat lubang biopori sedalam 2 meter dilakukan oleh 5 orang dalam waktu 2 hari, karena sifat tanah yang tidak dapat menyerap air. Namun berkat kesungguhan CSR PT. Indocement Citeureup , kini dilahan tersebut tumbuh berbagai tanaman Energy Crops seperti Jarak, Nyamplung, Kemiri Sunan, King Grass,Sorgum, Gundrowo. Tujuan utama penanaman di lahan-lahan pasca tambang yang marginal ini selain budidaya tanaman alternatif, juga untuk penghijauan (mengurangi emisi), menyerap $\mathrm{CO}_{2}$ (polusi), serta merevitalisasi lahan misalnya dengan menanam beberapa jenis pohon Jati, Pohon Jati terkenal sebagai salah satu pohon yang dapat memperbaiki kondisi tanah.

Menurut Bapak Fajar informan dalam penelitian ini, proses pengembangan energi alternatif dilakukan secara terus menerus oleh PT. Indocement Citeureup. Sejak tahun 2007 hingga saat ini dilakukan berbagai inovasi berkaitan dengan keberhasilan budidaya tanaman Jarak. Untuk budidaya tanaman Energy Crops lainnya dilakukan uji coba di P3M, menurut Bapak Aditya perusahaan terus menerus melakukan inovasi agar diperoleh biofluel semaksimal mungkin. Sebagai bentuk realisasi program yang etis, proses tersebut dimaknai sebagai suatu tanggung jawab yang harus dilaksanakan oleh perusahaan apapun resikonya. Menurut beliau ada juga beberapa kendala tapi itu dihadapi sebagai suatu tantangan yang kemudian dicari solusinya.

Beberapa bahan yang dicampurkan dalam proses pembakaran bersama bahan bakar batu bara pada pengolahan industri semen pada umumnya adalah sebagai upaya untuk mengurangi dampak buruk akibat proses tersebut, seperti polusi udara, pemanasan global, polusi debu dan dampak buruk lainnya. Sejak lama para pengusaha menggunakan beberapa bahan sebagai campuran yaitu seperti sebuk gergaji dan sekam padi.

Pilihan lainnya dalam program pengembangan bahan bakar alternatif oleh PT. Indocement Citeureup adalah Kemiri Sunan. Tanaman ini banyak ditanam di Jawa Barat, tumbuh dan berproduksi dengan baik pada daerah yang mempunyai curah hujan tahunan terendah, sehingga sangat tepat ditanam di lokasi pertambangan.

Minyak Kemiri Sunan dapat dimanfaatkan untuk berbagai keperluan seperti sebagai insektisida alami yang sangat efektif untuk membunuh hama dan berpotensi sebagai sumber bahan bakar nabati. Untuk budidaya kemiri sunan PT. Indocement menanam di quary dan telah mulai panen. Secara ekonomi komunitas yang menjadi tenaga kerja mendapat penghasilan tambahan dari budidaya ini, sesuai tujuan CSR perusahaan maka dalam program pengembangan tanaman energi alternatif ikut mendorong peningkatan ekonomi masyarakat (komunitas), sekaligus peningkatan pemahaman dan keterampilan mereka dalam bidang pertanian serta memelihara lingkungan yang berkesinambungan.

Tanaman energi alternatif lain yang dikembangkan oleh PT. Indocement operasional Citeureup adalah pohon Maja. Tanaman Maja merupakan salah satu tanaman yang diunggulkan sebagai tanaman energi alternatif atau energi terbarukan. Buah ini memiliki nama latin Aegle Marmelos mengandung glukosa yang sangat tinggi sehingga dapat diolah menjadi bioetanol. Adapun tanaman energi alternatif yang sudah mulai digunakan adalah tanaman Jarak Pagar (Jathropa Curcas). PT. Indocement sejak 2007 sudah mencurahkan perhatian pada jarak pagar sebagai penghijauan di lahan-lahan tambang, menyerap $\mathrm{CO}_{2}$, juga untuk dimanfaatkan buahnya sebagai bahan bakar alternatif. Adapun budidaya Tanaman Jarak/ Energy Crops oleh PT. Indocement dilatarbelakangi oleh kepentingan 
perusahaan akan bahan bakar alternatif substitusi batu bara, tanggung jawab melakukan revitalisasi dan reklamasi lahan bekas tambang, penghijauan dan penyerapan emisi Gas Rumah Kaca (GRK) secara hayati.

Tanaman lain yang dibudidayakan oleh PT. Indocement Citeureup adalah pohon Jati. Beberapa jenis pohon Jati dipilih untuk dikembangkan sebagai tanaman unggulan. Menurut Bapak Rizalyang bekerja di P3Mbahwa tanaman Jati ditanam lebih kepada kepentingan akan peneduhan dan penyerapan $\mathrm{CO}_{2}$. Namun tanaman Jati juga dapat dimanfaatkan untuk merevitalisasi lahan, karena sifat dari tanaman Jati antara lain adalah menyuburkan tanah.

Berkaitan dengan penelitian di Citeureup aplikasi etika bisnis direalisasikan dalam budidaya tanaman energi alternatif yang ramah lingkungandenmengurangi dampakburukakibat operasional pabrik. Ada beberapa point penting yang dianggap dan diterima sebagai bagian yang tidak lagi terpisahkan dari tanggung jawab sosial yaitu tanggung jawab sosial dan moral perusahaan terutama terwujud dalam bentuk ikut melakukan kegiatan tertentu yang berguna bagi masyarakat; perusahaan telah diuntungkan dengan mendapat hak untuk mengelola sumber daya alam yang ada dalam masyarakat dengan mendapatkan keuntungan bagi perusahaan tersebut; perusahaan merasa punya kepedulian, punya tanggung jawab terhadap masyarakat serta tidak merugikan masyarakat melalui kegiatan bisnisnya; keterlibatan perusahaan dalam berbagai kegiatan sosial akan memberi dampak yang positif dan menguntungkan bagi kelangsungan bisnis perusahaan.

Penggunaan energi alternatif atau energi terbarukan merupakan langkah yang dilakukan perusahaan guna ikut menjaga keberlangsungan kehidupan di masa mendatang. Secara bertahap PT. Indocement Tunggal Prakasa, Tbk. mengurangi penggunaan energi fosil serta menggantikannya dengan energi terbarukan yang lebih ramah lingkungan, seperti sekam padi dan serbuk gergaji pada awalnya. Kemudian ditambahkan penggunaan energi alternatif lain sejak 2007 yaitu minyak dari biji tanaman jarak pagar, terus berkembang dengan berbagai temuan tanaman-tanaman dengan energi alternatif yang disebut Energy Crops. Saat ini mulai dilakukan berbagai eksperimen berkenaan dengan pemanfaatan tanaman-tanaman tersebut seperti kemiri sunan, king grass, nyamplung dan lain-lain. Diharapkan beberapa tahun ke depan PT. Indocement akan fokus pada penggunaan energi terbarukan .(Lihat gambar 3)

Berger dan Luckmann, dalam Kuswarno (2009: 112) menjelaskan: "seseorang hidup dalam kehidupannya mengembangkan suatu perilaku yang repetitif, yang mereka sebut sebagai "kebiasaan" (habits). Kebiasaan memungkinkan seseorang mengatasi suatu situasi secara otomatis. Ketika seseorang memainkan suatu peranan yang dia adopsi dari perilaku yang terbiasa, orang lain berinteraksi dengannya sebagai suatu bagian dari institusi.

Program pengelolaan lingkungan berkelanjutan bersama masyarakat bukan saja melakukan pemberdayaan terhadap masyarakat, tetapi lebih jauh adalah menanamkan kebiasaan hidup peduli lingkungan serta menanamkan kesadaran untuk menjaga lingkungan secara berkelanjutan. Komunikasi dan interaksi yang dilakukan tentu membutuhkan waktu yang panjang, selain melalui Bilikom Bapak Fajar juga terjun langsung ntuk dapat bertatap muka dengan masyarakat komunitas. Dengan pendekatan yang terus menerus diharapkan akan dapat membentuk pola kebiasaan pada masyarakat sehingga lambat laun akan terbentuk komunitas yang memiliki kesadaran yang tinggi terhadap lingkungan berkelanjutan. Akan berkembang peranan yang tepat dari tiap-tiap individu dalam komunitas yang bila berinteraksi dengan pihak lain diharapkan akan membawa pesan dan kesan tentang kepedulian terhadap lingkungan tersebut. Secara disadari ataupun tidak, di dalam kelompok akan terbentuk semacam "aturan" yang dipatuhi bersama seperti ketika membudidayakan tanaman Jarak Pagar bukan untuk diambil kayunyaataupun bagian lainnya, melainkan untuk diambil buahnya saja dan diolah menjadi energi alternatif yang ramah lingkungan. Pohon dipelihara untuk mengurangi emisi, mengurangi polusi, peneduh, penghijauan, menjaga hara tanah, serta menjaga kualitas air.

\section{SIMPULAN}

Dari uraian di atas maka pemahaman pengusaha terhadap kegiatan CSR (Budidaya Energy Crops) adalah:(1) Pengusaha memahami kegiatan CSR (Budidaya Energy Crops) sebagai tanggung jawab perusahaan dalam memenuhi kebutuhan masyarakat. Dalam hal ini perusahaan 
membantu meningkatkan kualitas hidup masyarakat serta meningkatkan kehidupan ekonomi masyarakat, (2) Pengusaha memahami kegiatan CSR (Budidaya Energy Crops) sebagai tanggung jawab perusahaan dalam mewujudkan lingkungan hijau. Dalam hal ini perusahaan meningkatkan kesadaran masyarakat akan lingkungan hijau, dan bersama-sama masyarakat mewujudkan lingkungan hijau melalui berbagai program "go green", (3) Pengusaha memahami kegiatan CSR (Budidaya Energy Crops) sebagai tanggung jawab perusahaan dalam menanamkan kesadaran kepada masyarakat akan lingkungan berkelanjutan, melalui pelatihan dan pendampingan, Dalam hal ini perusahaan membangun kesadaran masyarakat akan pentingnya menjaga serta memelihara lingkungan agar terjaga kelestariannya serta memberikan manfaat yang besar bagi generasi sekarang maupun di masa depan, dan (4) Pemaknaan pengusaha PT. Indocement mengenai tanggung jawab lingkungan menurut peneliti sesuai dengan peraturan dan standar internasional. PT. Indocement dapat meraih penghargaan baik di tingkat nasional, maupun internasional.

Saran yang peneliti berikan berdasarkan hasil penelitian ini diantaranya (1) PT. Indocement Tunggal Prakasa, Tbk. khususnya di Citeureup sebaiknya meningkatkan aktivitas forum tatap muka dengan komunitas, agar komunitas dapat lebih leluasa menyampaikan aspirasinya, (2) Perusahaan sebaiknya lebih meningkatkan kegiatan sosialisasi programnya melalui media lokal, misalnya membuat radio komunitas, agar masyarakat dapat merasa lebih dekat dengan perusahaan, dan (3) Perusahaan sebaiknya lebih selektif dalam memilih program yang sesuai dengan kebutuhan komunitas, agar setiap program dapat memenuhi harapan komunitas.

\section{DAFTAR PUSTAKA}

Ardianto, E. (2010). Metodologi penelitian untuk public relations. Bandung: Simbiosa.

Bajari, A. (2012). Anak Jalanan, Dinamika Komunikasi dan Perilaku Sosial Anak Menyimpang, Bandung: Humaniora.

Bungin, B. M. (2007). Penelitian kualitatif: komunikasi, ekonomi, kebijakan publik, dan ilmu sosial lainnya. Jakarta: Kencana Prenada Media.

Bungin, B. (2010). Analisis data penelitian kualitatf. Jakarta: Raja Grafindo Persada.

Cresswell, J. W. (2011). Qualitative inquiry and reseach design: chosing among five tradition. London: Sage Plubication, Inc

Littlejohn, W. S. \& Foss, A. K. (2009). Teori komunikasi/ theories of human communication. Jakarta: Salemba Humanika.

Mulyana, D. \& Solatun. (2007). Metode penelitian komunikasi. Bandung: Rosda.

Mursitama, N. T., Hasan, F. M. \& Fakhrudin, Y. I. (2011). Corporate social responsibility (CSR) di Indonesia, teori dan implementasi: studi kasus community development Riau pulp. Jakarta: INDEF.

Morissan, Wardhani, C. Andy \& Hamid, F. (2010). Teori komunikasi massa: media, budaya, dan masyarakat. Bogor: Ghalia Indonesia.

Salim, A. (2006). Teori dan paradigma penelitian sosial. Yogyakarta: Tiara Wacana.

Solihin, I. (2008). Corporate social responsibility from charity to sustainability. Jakarta: Salemba Empat.

Rachman, N. M, Dkk. (2011). Panduan lengkap perencanaan CSR. Jakarta: Penebar Swadaya. 